\title{
Adapting Textbooks to Reflect Student Needs in Cambodia and the ASEAN Region
}

\author{
Chea Kagnarith \\ Australian Centre for Education, Cambodia \\ Alan Klein \\ University of British Columbia, Canada \\ John Middlecamp \\ Educational Consultant, Canada
}

\begin{abstract}
The authors first discuss the emergence of English as a lingua franca in Cambodia and elsewhere in Southeast Asia, and the emergence of Kirkpatrick's (2011) multilingual model of English teaching in the region. They then consider the importance of textbook adaptation as a way of supporting this new paradigm and the role that non-native-speaking teachers have in creating these adaptations. A detailed example of textbook adaptation, which explains (1) why to consider adapting materials and (2) how to make well-considered, manageable changes, is then provided as a model for practioners to consider. Finally, some practical concerns teachers might have about texbook adaptations are addressed.
\end{abstract}

A Japanese-coordinated meeting between delegates from Cambodia and Colombia to plan training in rural land-mine removal took place in October 2010 in Phnom Penh, Cambodia. No representatives from an English-speaking country participated. In which language was the training held? Not surprisingly, the answer is English. (S. Nem, personal communication, March 20, 2011).

This is just one example of how English is already used in Cambodia as a means of communication between people who do not share it as their first language. Such interaction in Cambodia and the other members of ASEAN (Association of Southeast Asian Nations) will continue to grow. This growth is due, at least partially, to (1) the fact that use of English as the organization's sole working language is already mandated (Association of Southeast Asian Nations, 2007) and (2) the promotion of "English as an international business language at the work place" being one objective of ASEAN's plans for regional integration in 2015 (ASEAN Secretariat, 2009, p. 3). Clearly, English use among non-native speakers is taking on an everincreasing role in the spread of professional information in the region.

Language Education in Asia, 2012, 3(2), 218-229.

http://dx.doi.org/10.5746/LEiA/12/V3/I2/A10/Chea_Klein_Middlecamp 
This article briefly reviews Kirkpatrick's "multilingual model" of English teaching (2011, p. 221) as a rationale for continued professional development for teachers that aims to challenge traditional assumptions about textbook use and hone the skills necessary for teachers to modify textbook materials to help their learners use English as a lingua franca (ELF). For the purposes of this article, Kirkpatrick's (2011) basic definition of ELF, English that is used in conversation by two or more people who do not share the same first language (L1), is used.

\section{Moving Toward a Multilingual Model of ELT in Cambodia and the ASEAN Region}

Despite the fact that communication between non-native speakers now constitutes the majority of interactions in ELF worldwide, teachers and learners continue to rely on native-speaker models as the ultimate standards for judging English language learning (Seidlhofer, 2005). Kirkpatrick (2010, 2011), reflecting on this paradox in Cambodia and the ASEAN region, described a regional English that has some nonstandard grammatical and pronunciation features. He then proposed a different set of benchmarks for measuring students' progress: the skills needed by multilingual learners in the ASEAN region as they move toward a Southeast Asian English. His main argument is that Cambodian speakers of English, for instance, do not need merely to imitate native speakers, but instead must reach a level of mutual intelligibility with their regional peers. In other words, a speaker's reason for using the language determines when a regional variation is an acceptable alternative to standard varieties of English (e.g., for day-to-day work conversation with non-L1 speakers) and when it is not (e.g., in preparing for standardized tests such as IELTS or TOEFL).

Based on this concept, Kirkpatrick (2011, p. 221) suggested a "Multilingual Model of ELT," in which multilingual English teachers become the preferred linguistic role models for ASEAN students. Two pioneering studies of English language learners in Cambodia indicate that this model could already be beginning to take hold in the country. Keuk (2008, p. 98) succinctly described Cambodia's specific language-learning context as one where "learners who have attended English language training centers and institutions run by Cambodian institutions ... pick up another kind of English variety, hybridized between either of the [American or British] models, and their mother tongue, Khmer." Young Cambodians, he added, are already using this blend of language-learning input to create successful communication for personal, educational, and work-related purposes. Moore and Bounchan's (2010) survey of the opinions of students at the Institute of Foreign Languages at the Royal University of Phnom Penh regarding the value of Cambodian ELT faculty there found that a growing minority of learners appreciated the value of Cambodian teachers of English because of "how they could help their students to learn English, whereas native English speakers seem to be valued only as role models for English pronunciation and spoken interaction" (p. 123). While this finding might not hold true in other settings, the possible emergence of a trend is an intriguing area for future research. At present, it seems clear from both Keuk as well as Moore and Bounchan's observations that at least some Cambodian students are developing and articulating their own sense for when instruction by a native speaker is advantageous (e.g., for models of pronunciation) and when local teachers are more effective (e.g., providing "cultural understanding of issues" and explaining English grammar in the L1) (Moore \& Bounchan, p. 123). Thus, it is fair to say that local, non-native-speaking English teachers, especially those who are well versed in both regional and standard varieties of English, are in a strong position to help their students. In addition, by being aware of the language goals that their students have set for themselves, these teachers can best decide whether, and for which students, grammar and pronunciation instruction must aim toward international intelligibility or a native-like result. 


\section{The Teacher's Role in Adapting Textbooks}

Kirkpatrick (2011) observed, however, that progress in developing regional varieties of English is being impeded by standardized textbooks and other materials currently in use, specifically American and British texts that largely present native-speaker norms. This is certainly a situation unlikely to change anytime soon, as Tomlinson (2006, p. 131) remarked:

... all the coursebooks I know which are sold on the global market still use one of these prestige standards as their model of correctness. It would be a brave publisher who risked financial failure by publishing a global coursebook with an EIL core or a variety of world Englishes as its model(s).

Fortunately, teachers in Cambodia and throughout the ASEAN region need not wait for either daring publishers or innovative government policies to start moving toward an ELF multilingual model of teaching. Teachers themselves can start by making small adaptations in existing, widely used textbooks. The current reality is, however, that many instructors are hesitant to make any changes in the textbook, even if their school directors allow it. This hesitancy, Richards suggested, is often based on the following assumptions about textbooks (1998, cited by McGrath, 2002):

- Everything in a lesson is equally important for students.

- Explanations and cultural information in textbooks should not be questioned.

- Teachers do not have the authority or expertise to adapt textbook lessons.

- Activities in a textbook are always superior to those created by teachers.

In addition to these beliefs, another factor might limit teachers' willingness to modify text activities: lack of experience. However, despite these factors, some Cambodian teachers have come to recognize that textbook adaptation is not only important, but also achievable, even for teachers who have limited classroom experience. As shown below, all teachers can learn to logically, systematically, and simply make changes to their textbook material that will contribute greatly toward student success in local and international contexts.

\section{The Why}

\section{Why and How to Adapt Materials}

Once teachers have accepted the idea that they can make changes to the text, the decision to change has to be made based on the content of each activity. While the objective of an activity may be important for students, its presentation might be too simple or uninteresting for them. Of course, care is required before making major changes to textbooks, since doing so could undermine the student-teacher relationship--students might, for example, question the teachers' judgment or resent paying for a textbook that is not fully used. Thus, deciding wisely whether to use an activity (and if so, to use it as is or to modify it) or not to use it (and then whether to simply omit the activity or replace it with another) (Harmer, 2007) is the key to good textbook adaptation. Furthermore, if a decision has been made to adapt an activity to better meet the needs of a particular classroom, the teacher must have and be able to articulate a clear idea why the material in the text needs to be made better. Among the reasons McGrath (2002) offers teachers to consider when they are contemplating adaptation of material are the following: 
- To localize it, by replacing a Western setting or context with local or regional ones that let students focus more on language objectives, rather than on the culture (e.g., preview a lesson on city life by showing and discussing with students a photo of a local police officer before they read a text centered on a British "bobby").

- To personalize it, by devising examples and activities that relate directly to students, ones that reflect their academic or professional interests and let them use their life experience and learned knowledge (e.g., help students create menus in English featuring their favorite local dishes before they read a text focusing on a Western restaurant menu).

- To modernize it, by updating language or cultural settings that seem out of date (e.g., read aloud or have students read a recent article in English on a work-related issue, such as the use of mobile phones in the workplace, from an online news source or local newspaper before they listen to a dialogue set in a conventional office).

- To simplify it, by streamlining procedures to make activities more accessible. (e.g., edit texts to reduce linguistic difficulty or break down complex tasks into more manageable pieces).

\section{The How}

Any of the above aims can be useful in determining why to customize textbook lessons; however, a teacher must also decide how to adapt an activity, which can be especially difficult when time and resources are scarce. Fortunately, Harmer (2007, p. 183) offers a concise set of techniques for implementing text changes (rearranged from the original list to reflect their relative ease of use):

- Re-ordering parts of a lesson or lessons within a unit. Example: If many students in the class find the reading exercises difficult, start with the lesson's listening activity to introduce key ideas and vocabulary before they begin the reading.

- Reducing by cutting out activities that are not necessary for learners to achieve the lesson's objectives. Example: When doing in-class exercises on what is usually considered a difficult grammar point, such as using relative clauses as modifiers, move on before completing all of the exercises if the class already "gets it" and doesn't need further practice.

- Adding more practice or other activities. Example: If, unlike in the situation above, students are struggling with relative clauses, create simple activities (e.g., have students work in groups to use relative clauses to write and share descriptions of important people or places in the community).

- Re-writing or replacing material with Internet-based or "home-grown" resources. Example: After students skim a textbook reading on transport that describes subway systems around world, help them use the format of the article to write their own articles on the use of tuk-tuks, mototaxis, and trucks as means of public transport. 
This, of course, is not an all-inclusive list. Any of these techniques can be combined within a single activity, and teachers can also develop their own types of text adaptations.

A key to the revision process, Harmer concluded, is remembering "that students need to be able to see a coherent pattern to what we are doing and understand our reasons for change" (2007, p. 183). So if an activity provides practice in using the present perfect and the teacher substitutes a different grammar point (e.g., present continuous), the teacher must be able explain why that change was made, especially if it deviates from the lesson objectives. Then, should a school director or a student ask why the text was modified, the instructor will be able to offer a convincing reason (because, for example, the text has covered present perfect repeatedly and the students, in fact, need more practice in the present continuous). A final point for teachers to remember, however, is that there is nothing inherently wrong with using the textbook as is; only when a text lesson does not adequately reflect the needs and interests of learners must changes be considered. The textbook activity below demonstrates how a commonplace lesson can be made more effective by increasing its relevance to students.

A hypothetical textbook example. The example listening exercise shown in Appendix A is a starting point to demonstrate how teachers can fine-tune an activity to increase student interest in a pre-intermediate class, always keeping in mind that the most important guiding principle is to stay focused on the objective of the activity (this activity is modeled after a frequently used type of classroom activity and is not from a commercial textbook). Below is some background information to consider before analyzing the activity:

- Travel is a common subject covered in textbooks because it is a universally interesting topic for students.

- Many texts discuss places that are either unknown to students in the ASEAN region or are not realistic for them to visit.

- This is a listening activity practicing superlatives, at a pre-intermediate to intermediate level.

Analyzing the activity. Answering questions about the content of an activity, as shown in the rubric below, can help teachers make a decision about whether they should adapt this listening activity (or any other type of activity) for their classroom. 


\begin{tabular}{|c|c|c|}
\hline Question & Response & $\begin{array}{l}\text { Suggestions for } \\
\text { Textbook Adaptation }\end{array}$ \\
\hline $\begin{array}{l}\text { What is the } \\
\text { objective of the } \\
\text { activity? }\end{array}$ & Practicing superlatives & $\begin{array}{l}\text { Be sure to keep the grammar point } \\
\text { as the main focus of the revised } \\
\text { activity. }\end{array}$ \\
\hline $\begin{array}{l}\text { Is the material } \\
\text { at an } \\
\text { appropriate } \\
\text { level for the } \\
\text { students? }\end{array}$ & $\begin{array}{l}\text { No, there are two new areas of } \\
\text { study being introduced at the same } \\
\text { time (adjective forms, and } \\
\text { information about the cities). } \\
\text { This is also a listening activity, and } \\
\text { these are generally difficult for } \\
\text { students. }\end{array}$ & $\begin{array}{l}\text { Consider spending more time on } \\
\text { this activity and reducing time } \\
\text { spent on less important activities in } \\
\text { the lesson. }\end{array}$ \\
\hline $\begin{array}{l}\text { Is the activity } \\
\text { important? }\end{array}$ & $\begin{array}{l}\text { Yes, because the students need } \\
\text { practice activities concerning this } \\
\text { grammar point. }\end{array}$ & $\begin{array}{l}\text { Be sure the revised activity gives } \\
\text { students plenty of opportunity to } \\
\text { practice use of the new grammar } \\
\text { point. }\end{array}$ \\
\hline $\begin{array}{l}\text { Is the activity } \\
\text { interesting to } \\
\text { students? }\end{array}$ & $\begin{array}{l}\text { Not really, because the students } \\
\text { have little or no knowledge of the } \\
\text { cities in the dialogue. }\end{array}$ & $\begin{array}{l}\text { Modify the activity by localizing it } \\
\text { (replacing foreign place names } \\
\text { with Cambodian ones) so students } \\
\text { will more easily remember the } \\
\text { material. }\end{array}$ \\
\hline
\end{tabular}

Figure 1. A sample rubric for deciding whether and how to adapt a textbook activity, with possible reponses and suggestions for adaptations.

Analyzing, implementing, and adjusting the changes made. As shown in Appendix $B$, the conversation can be rewritten, based on the above considerations, by changing the interaction to a dialogue with a hotel clerk. Using McGrath (2002) and Harmer's (2007) suggestions, the material could be localized to the ASEAN region and unfamiliar world city names could be replaced by those of Cambodian towns. Because the objective is to demonstrate the use of superlatives, the easiest textbook activity for students to complete would be a cloze exercise where students read the transcript while listening and filling in missing key words, mainly superlatives, from the conversation. An alternative would be for students to match the superlative with the accompanying noun, as in the exercise shown in Appendix C.

To make this revised listening activity most beneficial in a school setting, a teacher could find a colleague to record the conversation. The recording could then be saved for future use, ideally in an organized library of shared materials. However, if that is not possible, the teacher could read the rewritten conversation to the students, or students could role play the conversation themselves. Alternatively, using McGrath's (2002) ideas, the material could be personalized so that students develop their own dialogue in which they discuss their favorite cities or places. Likewise, the instructions could be simplified or changed (e.g., part of the exercise could be already done for students), so that students would be more likely to understand the purpose of the activity. Additionally, following Harmer's (2007) suggestion, the activity could be reordered so that it comes at a different part of the unit (e.g., if time permits, use the localized version of the dialogue first and then have the students study the original dialogue as a review, as suggested below). 


\section{Addressing Possible Concerns About Adaptation}

One potential criticism of adapting listening material is that many students in Cambodia and other areas do not have many possibilities to hear English spoken by native speakers, so if the interview is recorded by Khmer speakers of English, the students have one less native-speaker sample. That is a fair concern, but this is where the teacher must weigh the benefit (e.g., extended focus on a key grammar point) against the negative of losing an opportunity to listen to the textbook dialogue. However, it must be remembered that virtually all commercially produced texts provide numerous opportunities for students to hear native speakers and that at least some outside exposure to native-produced language is available, even in isolated areas (e.g., through BBC, VOA, or Radio Australia Asia Pacific FM broadcasts). Another concern is that learning cultural information (e.g., about different world cities) is important in its own right as cultural exposure for students, so some teachers might not want to deprive their students of this experience. If that is the case and a teacher has time, he or she can do a localized activity first, and then use the original textbook activity for review. A third issue is that textbook adaptation can be time-consuming, but there are at least two ways to reduce that burden: (1) by collaborating with other teachers to reduce the workload and build professional camaraderie, and (2) by using student input to assist the teacher in localizing, personalizing, modernizing, and simplifying material (this approach offers students a more active, engaging role in their learning as well).

These potential problems and possible solutions are summarized below in Figure 2 .

\begin{tabular}{|l|l|}
\hline \multicolumn{1}{|c|}{ Possible Concern } & \multicolumn{1}{c|}{ Proposed Solution(s) } \\
\hline $\begin{array}{l}\text { Reduced student exposure to native-speaker } \\
\text { input }\end{array}$ & $\begin{array}{l}\text { Continue to use other recorded native- } \\
\text { speaker input from the textbook and other } \\
\text { available sources (e.g., radio broadcasts or } \\
\text { podcasts). }\end{array}$ \\
\hline $\begin{array}{l}\text { Reduced student exposure to new cultural } \\
\text { information }\end{array}$ & $\begin{array}{l}\text { Use the original activity as part of a review } \\
\text { of lesson objectives. }\end{array}$ \\
\hline Increased preparation time for teachers & $\begin{array}{l}\text { Collaborate with other teachers in revising } \\
\text { materials. } \\
\text { Create a shared collection (library) of } \\
\text { revised materials. } \\
\text { Let students develop their own } \\
\text { modifications to the text material } \\
\text { (personalizing the activity). }\end{array}$ \\
\hline
\end{tabular}

Figure 2. Concerns about adaptations and solutions addressing those concerns.

\section{Conclusion}

In developing countries such as Cambodia, mastering English for effective communication in varying contexts can no longer be a "gold standard" achieved by only a few. All Cambodian teachers and learners must have a role in the development of a mutually intelligible ASEAN English. As Yano (2009) notes, 
The time will come when it will no longer matter whether you naturally acquire English in the English-speaking community; it will only matter how proficient you are in understanding others and being understood by others in English. It will not matter where you have learned the language. (p. 253)

As was noted earlier in this article, the "time" Yano refers to is already arriving in the region. Cambodian teachers and others must be willing to customize text material that has not caught up with ELT's new reality. By doing so, they will take a vital step in helping their students to join the regional and global communities of multilingual speakers who can use English successfully in their professional and personal lives.

\section{Author Note}

Chea Kagnarith, ACE Santhor Mok, Phnom Penh, Cambodia; Alan Klein, University of British Columbia English Language Institute, Vancouver, Canada; John Middlecamp, Educational Consultant, Vancouver, Canada.

The authors would like to thank Layne Kriwoken for his assistance in developing the textbook activity.

Correspondence concerning this article should be addressed to Kagnarith Chea, ACE Santhor Mok, \#657 Kampuchea Krom Blvd., Khan Touk Kork, Phnom Penh, Cambodia. Email: kagnarith.chea@idp 


\section{References}

ASEAN Secretariat. (2009, June). ASEAN socio-cultural community blueprint. Retrieved from http://www.aseansec.org/5187-19.pdf

Association of Southeast Asian Nations. (2007, November 20). The ASEAN charter (Article 34). Retrieved from http://www.aseansec.org/publications/ASEAN-Charter.pdf

Harmer, J. (2007). The practice of English language teaching (4th ed.). Harlow, England: Pearson Education.

Keuk, C. N. (2008). English language variety in Cambodia. CamTESOL Conference on English Language Teaching: Selected Papers, 4, 98-107.

Kirkpatrick, A. (2010). Learning English in ASEAN: Myths and principles. Language Education in Asia, 1(1), 1-7. http://dx.doi.org/10.5746/LEiA/10/V1/A02/Kirkpatrick

Kirkpatrick, A. (2011). English as an Asian lingua franca and the multilingual model of ELT. Language Teaching, 44(2), 212-224. http://dx.doi.org/10.1017/S0261444810000145

McGrath, I. (2002). Materials evaluation and design for language teaching. Edinburgh, Scotland: Edinburgh University Press.

Moore, S. H., \& Bounchan, S. (2010). English in Cambodia: Changes and challenges. World Englishes, 29(1), 114-126. http://dx.doi.org/10.1111/j.1467-971X.2009.01628.x

Seidlhofer, B. (2005). Key concepts in ELT: English as a lingua franca. ELT Journal, 59(4), 339341. http://dx.doi.org/10.1093/elt/cci064

Tomlinson, B. (2006). A multi-dimensional approach to teaching English for the world. In R. Rubdy \& M. Saraceni (Eds.), English in the world: Global rules, global roles (pp. 130150). London, England: Continuum.

Yano, Y. (2009). English as an international lingua franca: From societal to individual. World Eng/ishes, 28(2), 246-255. http://dx.doi.org/10.1111/j.1467-971X.2009.01587.x 


\section{Appendix A \\ Listening Passage from a Hypothetical Textbook}

\section{Where to Go?}

Charles cannot decide where to go on holiday this year, so he attends a travel fair. He talks to tourism officials from three cities sitting at a table: Mexico City, Paris, and Sydney.

Charles: $\quad \mathrm{Hi}$, l'm interested in finding out about the most interesting places to visit in Mexico City.

Representative 1: Well, you can visit the best sites in Mexico City. Most visitors start their tour of my city at the Zocalo, which is the biggest public square in Mexico. You'll also want to be sure to see the Fine Arts Palace. It's the most beautiful theater in Mexico City, so you don't want to miss taking a tour of the inside of the building.

Charles That sounds like a really interesting place to visit.

Representative 1: I think you'll like it a lot. Finally, every visitor goes to the Museum of Anthropology, which has the largest collection of ancient Mexican artifacts in the country. You could spend the whole day there. And best of all, the weather in Mexico City is great.

Charles: Okay, thanks for the information. Is it true that tourists say that Paris is the greatest city in the world?

Representative 2: Oh, yes, they really do say that. Everyone wants to go to the Eiffel Tower, which is the place to see the most incredible views of the city from the top. Of course, you don't want to miss the Louvre Museum, where you can find the most famous painting of all time, the Mona Lisa.

Charles: I can't go to Paris and not see the Mona Lisa.

Representative 2: That's for sure. However, you don't want to miss taking a boat ride on the Seine River. Then you will know why Paris is called the most romantic city in the world.

Charles: $\quad$ That sounds great, but I hear that Sydney is the most exciting city for young tourists.

Representative 3: You're right, Sydney is the place to be if you're young and you love spending time outdoors. Of course, there's the world famous Sydney Harbour Bridge. The fastest guided climb up the Bridge only takes $21 / 2$ hours. Also, be sure not to miss walking around the incredible Sydney Opera House, the most unusual building in the city.

Charles: It must be great seeing the Opera House from the top of the Bridge.

Representative 3: It certainly is. Finally, for those who love sunshine, the Sydney beaches are the most enjoyable part of being in the city. Bondi Beach, one of the best known, is also the closest to downtown. So, Sydney has something for everyone.

Charles: Well, I appreciate you telling me about your three cities. It's so hard to make a decision; I guess l'll need to visit all three places. 


\section{Appendix B \\ Listening Passage: Localized Version}

\section{Where to Go?}

Charles is in Phnom Penh on holiday. This is his first time in Cambodia, so he is asking the hotel clerk for suggestions on places to visit in the country.

Charles: $\quad \mathrm{Hi}$, I'm interested in finding out about the most interesting sites to visit in Cambodia.

Hotel Clerk: Well, you can visit the most wonderful places in my country. Since you're already in Phnom Penh, you can start right here. Have you been to Wat Phnom yet?

Charles: $\quad$ No, I just arrived last night. What can I see there?

Hotel Clerk: Wat Phnom is the oldest religious site in the city. It's great and you'll love the wonderful monkeys there. The wat is very close to the river. While you're in the area, you can go down to the riverside at dusk.

Charles: Why do people go there at that time of the day?

Hotel Clerk: Oh, because that's when everyone goes there to walk and also do aerobic exercise. Join the biggest group of people exercising to music. They'll be having the best time.

Charles: $\quad$ That sounds good. What's the most important museum that visitors go to in Phnom Penh?

Hotel Clerk: Well, it's probably the saddest place to visit in the city, but all tourists go to Tuol Sleng, the Genocide Museum. You shouldn't miss it if you want to understand recent Cambodian history.

Charles: Okay, and I also want to go to Angkor Wat. What's the nearest town?

Hotel Clerk: Of course, Angkor Wat is really the most famous tourist destination in all of Cambodia. It has the largest collection of temples in Southeast Asia and is a UNESCO World Heritage Site.

Charles: $\quad$ So, what town is it near?

Hotel Clerk: It's very close to Siem Reap, and people say it has the nicest hotels and restaurants in the country. It will probably be the most exciting spot you visit in Cambodia.

Charles: That sounds great. I was also thinking about going to the beach. Can you suggest a place?

Hotel Clerk: There's one place everyone goes, and that's Sihanoukville. It's about 5 hours from Phnom Penh and has the most beautiful beaches in Cambodia.

Sihanoukville is famous for its food and has the tastiest seafood barbecue anywhere. When you get tired of the traffic and noise of Phnom Penh, go to Sihanoukville to enjoy the freshest air around.

Charles: Well, I appreciate you telling me about all the great places to visit in Cambodia. I'm going to have a good holiday here. 


\section{Appendix C \\ Listening Exercise}

\section{Matching}

Listen to the conversation between Charles and the hotel clerk. Draw a line between the superlatives that you hear on the left side and the matching nouns on the right. The superlative adjectives and accompanying nouns are not listed in the order heard in the conversation.

\section{Phnom Penh}

\section{Superlative}

1. saddest

2. oldest religious

3. most important

4. biggest

5. best

6. most interesting

7. most wonderful

\section{Noun}
a. places
b. time
c. sites
d. museum
e. site
f. group
g. place

\section{Siem Reap and Sihanoukville}

\section{Superlative}

1. most famous

2. most beautiful

3. largest

4. tastiest

5. freshest

6. nicest

7. most exciting

\section{Noun}

a. beaches

b. seafood barbecue

c. hotels and restaurants

d. spot

e. tourist destination

f. collection

g. air

\section{Follow-Up}

Create a superlative sentence using the words in brackets.

(Phnom Penh, crowded)

(Sihanouk, beautiful)

(Sihanouk, populated)

(Siem Reap, old)

(Phnom Penh, polluted) 